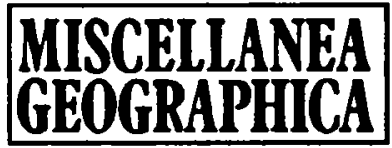

WARSZA WA 1996 Vol. 7

Krzysztof Olszewski

\title{
THE MACROTYPES OF ATMOSPHERIC CIRCULATION AND THE DIURNAL COURSE OF RELATIVE HUMIDITY
}

The circulation factors play an essential role in the shaping of weather and climatic conditions in temperate latitudes, because within this zone the greatest variability of atmospheric pressure configurations is observed. The influence of atmopsheric circulation on climate was known for a long time already. Thus, the history of the study of circulation and of its impact on climatic relations is quite a long one. In the initial period attention was focussed on the discrimination of circulation types, their frequency of appearance, as well as on the study of changes in appearance of definite circulation forms. The subsequent stage consisted in the analysis of the linkages between particular elements of climate and the circulation types. The greatest attention was devoted to the linkages with the air temperature. From among the publications which appeared in Poland let us note here those by Kossowska-Cezak (1982), Kozuchowski (1989) and Olszewski (1992). There are much less reports concerning other elements than air temperature.

The purpose of the present note is to show the results of analysis of the diurnal course of the relative humidity as a function of the macrotype of atmospheric circulation. The study was based upon the hourly observations made in the period 1956-1960 at the meteorological station Warsaw-Okęcie. It can be assumed that these observations are representative for the climatic conditions of central Poland. In definition of the circulation types the catalogue of Osuchowska-Klein (1978) was used, taking into account only circulations which were sufficiently similar to the model type. On this basis classification into circulation macrotypes was carried out (Osuchowska-Klein, 1973). Grouping was performed according to two criteria: first, taking into account the direction of advection of the air masses (the eastern and western circulation macrotypes), and the second, taking into account the air pressure configuration in which these air masses were arriving (the cyclonal and anticyclonal circulation macrotypes). Such generalizations are of practical significance in the analysis of the climatological features of circulation types and in weather forecasting, 
especially the long-term one. For the days with the thus determined macrotypes the average diurnal course of relative humidity was calculated, smoothed afterwards with the method of harmonic analysis.

Macrotypes of the eastern and western circulations. This class contains all the circulation types which are characterized by the inflow of air masses from the western sector (W - "maritime"), located to the West from the North-South direction, and from the eastern sector (E - "continental"), located to the East of this borderline (Osuchowska-Klein 1973).

The greatest differentiation of the diurnal course of relative humidity in the macrotypes of eastern/western circulation can be observed in the cooler part of the year (November-March). A higher diurnal average of relative humidity (even by as much as 6\%) is linked then with circulation from the western sector (see Fig. 1., Table 1). The nature of diurnal changes is similar. Diurnal amplitudes have alike values, and the differences between
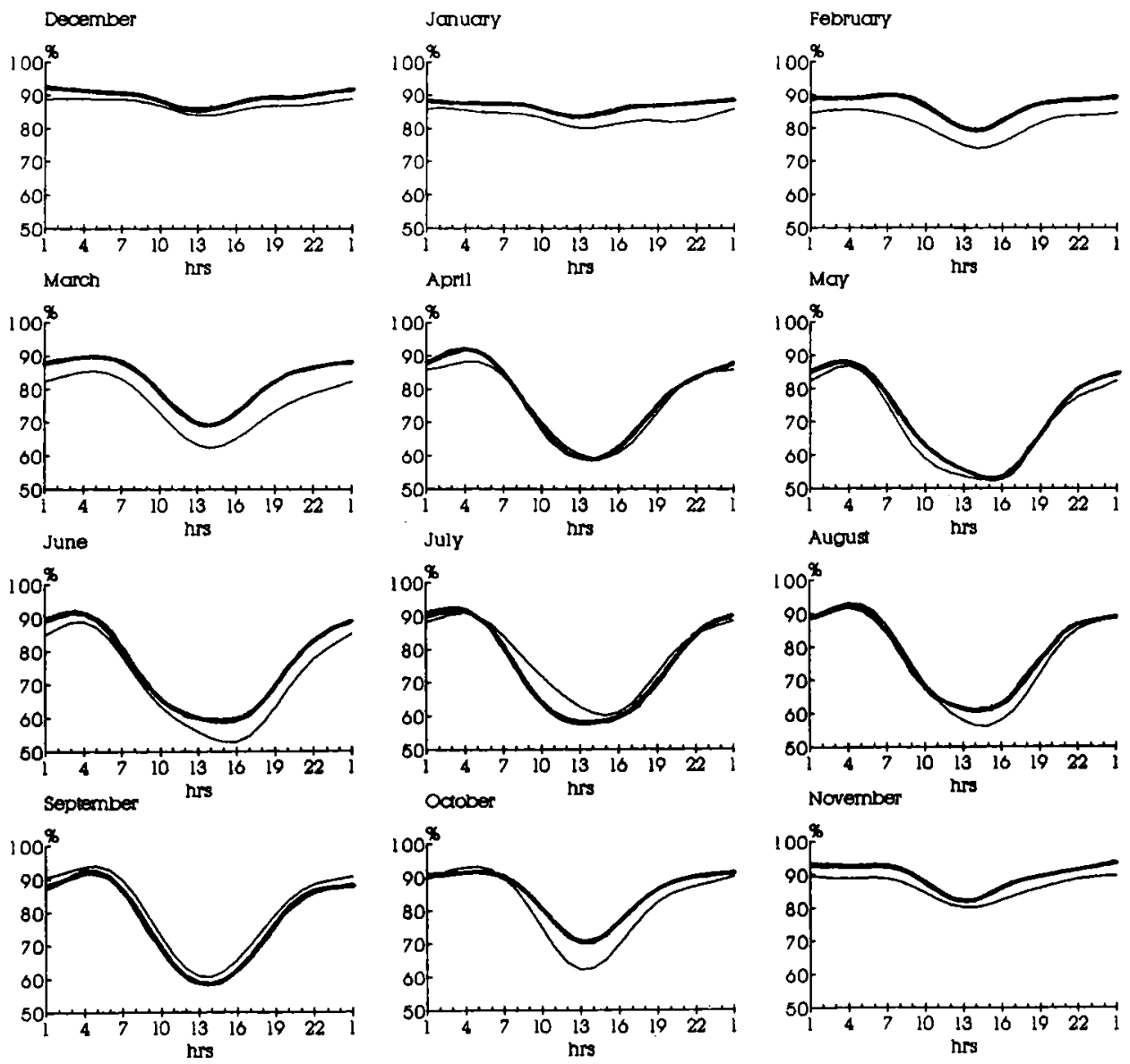

Fig. 1. Sinusoids of diurnal course of relative humidity in the eastern ( ) and western ( ) circulation macrotypes (Warsaw 1956-1960) 
the macrotypes persist during the whole 24-hour period on the same level $(\Delta f=3-9 \%)$.

Table 1

Mean relative humidity (\%) for circulation macrotypes (Warsaw 1956-1960)

\begin{tabular}{|c|c|c|c|c|c|c|c|c|c|c|}
\hline \multirow{2}{*}{ Month } & \multirow{2}{*}{ Type } & \multicolumn{5}{|c|}{ Humidity (\%) } & \multirow{2}{*}{ Type } & \multicolumn{4}{|c|}{ Humidity (\%) } \\
\cline { 3 - 7 } \cline { 8 - 11 } & & daily & min & max & ampl & & daily & min & max & ampl \\
\hline I & W & 87 & 83 & 88 & 5 & C & 85 & 81 & 87 & 6 \\
& E & 83 & 80 & 86 & 6 & A & 87 & 85 & 90 & 5 \\
\hline II & W & 86 & 79 & 90 & 11 & C & 85 & 75 & 89 & 14 \\
& E & 81 & 74 & 86 & 12 & A & 85 & 78 & 88 & 10 \\
\hline III & W & 82 & 69 & 90 & 21 & C & 84 & 72 & 91 & 19 \\
& E & 76 & 63 & 85 & 22 & A & 74 & 60 & 85 & 25 \\
\hline IV & W & 77 & 59 & 92 & 33 & C & 78 & 62 & 90 & 28 \\
& E & 76 & 59 & 88 & 29 & A & 74 & 56 & 89 & 33 \\
\hline V & W & 71 & 53 & 88 & 35 & C & 76 & 60 & 88 & 28 \\
& E & 69 & 52 & 87 & 35 & A & 68 & 50 & 87 & 37 \\
\hline VI & W & 74 & 59 & 90 & 31 & C & 79 & 64 & 92 & 28 \\
& E & 72 & 54 & 89 & 35 & A & 69 & 51 & 89 & 38 \\
\hline VII & W & 75 & 58 & 92 & 34 & C & 78 & 62 & 93 & 31 \\
& E & 77 & 60 & 91 & 31 & A & 73 & 56 & 89 & 33 \\
\hline VIII & W & 78 & 61 & 92 & 31 & C & 80 & 64 & 93 & 29 \\
& E & 76 & 56 & 93 & 37 & A & 74 & 53 & 93 & 40 \\
\hline IX & W & 78 & 59 & 92 & 33 & C & 82 & 67 & 91 & 24 \\
& E & 80 & 61 & 94 & 33 & A & 77 & 54 & 94 & 40 \\
\hline X & W & 84 & 70 & 92 & 22 & C & 84 & 70 & 92 & 22 \\
& E & 81 & 62 & 93 & 31 & A & 82 & 65 & 92 & 27 \\
\hline XI & W & 86 & 80 & 89 & 9 & C & 89 & 80 & 93 & 13 \\
& E & 89 & 82 & 93 & 11 & A & 87 & 82 & 91 & 9 \\
\hline XII & W & 89 & 85 & 92 & 7 & C & 90 & 86 & 92 & 6 \\
& E & 87 & 84 & 89 & 5 & A & 88 & 83 & 90 & 7 \\
\hline
\end{tabular}

Note: Circulation macrotype: $\mathrm{W}$ - western, $\mathrm{E}$ - eastern, $\mathrm{C}$ - cyclonic, $\mathrm{A}$ - anticyclonic

During the warmer part of the year (April through September) differentiation of the diurnal dynamics in these two macrotypes of circulation is small. The differences of the diurnal averages of relative humidity between the two circulation types do not exceed $2 \%$, and in definite hours $-3 \%$. During the 24-hour period bigger differentiation is observed around noon and in the evening. Similarly as in the winter season higher humidity is as a rule observed for the inflow of air masses with the western circulation. At around midnight the values of humidity in case of both circulation directions are similar.

The comparison of the diurnal course of the air humidity under various macrotypes of circulation directions makes it possible to state that they do not play an important role during the warmer part of the year, especially in 
the nighttime. More pronounced differences are only observed between November and March.

Macrotypes of the cyclonic (C) and anticyclonic (A) circulations. Differentiation of air humidity as a function of the barometric configuration takes a more clear shape between March and September, that is - during the warmer part of the year (Fig.2). The average diurnal values range then from $76 \%$ to $84 \%$ in the cyclonal macrotype, and from $68 \%$ to $77 \%$ in the anticyclonal one. The differences of humidity between the two macrotypes observed in particular months are not less than 5\% (Table 1). The range of fluctuations during the 24-hour period is quite differentiated. The average diurnal amplitude in the high pressure configurations is by $6-17 \%$ higher than in the low pressure ones.
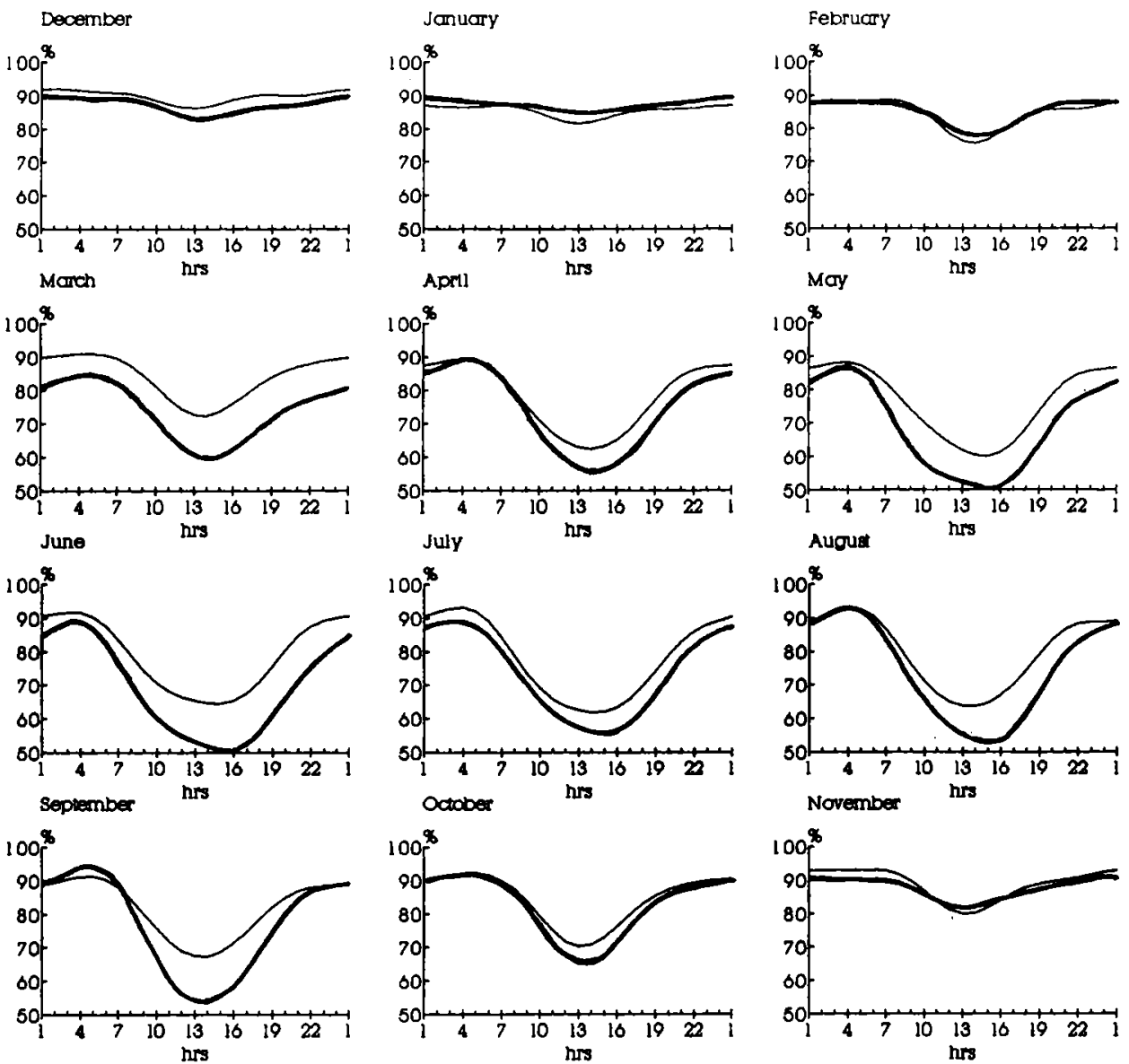

Fig. 2. Sinusoids of diurnal course of relative humidity in the cyclonic ( ) and anticyclonic ( ) circulation macrotypes (Warsaw 1956-1960) 
During the cooler part of the year (October-February) the nature of the barometric configuration does no longer play such an important role in the shaping of the diurnal changes of air humidity (Fig. 2). Somewhat higher values of humidity can be observed in the cyclonal settings. The diurnal averages change in the bracket of $85-90 \%$ (see Table 1). The range of diurnal fluctuations in both types is not very big, with the greater amplitudes observed, this time, in the cyclonal configurations.

The analysis of the diurnal changes of the relative humidity of the air has shown that they depend to a large extent on the macrotype of atmospheric circulation. In particular parts of the year either the direction of advection or the barometric configuration, in which it takes place, are decisive. During almost whole year (from Winter till Autumn) the decisive influence on the course of relative humidity of the air is exerted by the barometric configuration in which advection of air masses is taking place. In the cyclonal configurations humidity is distinctly higher than in the anticyclonal ones. The direction of advection does not play an important role in this case. Whether air flows in from the East or from the West the values of relative humidity are alike. It is only during Winter that the direction of the air flow gains bigger importance, while the role of the air pressure configuration diminishes.

\section{REFERENCES}

Kos s ow sk a-C ez ak U., 1982, Duże zmiany temperatury z dnia na dzień w Polsce (High temperature changes from day to day in Poland). Przeglad Geofizyczny, $27,3-4$.

Kożuchowski K., 1989, Makrotypy ogólnej cyrkulacji atmosfery a temperatura $w$ Polsce (The macrotype) of the general atmospheric circulation and the temperature in Poland). Przeglad Geofizyczny, 34, 4.

Olszew ski K., 1992, Macrotypes of atmospheric circulation and diurnal course of air temperature. Miscellanea Geographica, Warszawa.

Osuchowska-Klein B., 1973, Analiza rocznych przebiegów częstości występowania w Polsce makrotypw cyrkulacji atmosferycznej (The analysis of the annual courses of frequencies of appearance of the atmospheric circulation macrotypes in Poland, Przeglad Geofizyczny, 18, 3-4.

Osuchowska-Klein B., 1978, Katalog typów cyrkulacji atmosferycznej (The Catalogue of the Types of Atmospheric Circulation). WKiL, Warszawa. 
